\title{
Authenticity as a Political Act: Straub-Huillet's Chronicle of Anna Magdalena Bach and the Post-War Bach Revival
}

\author{
KAILAN R. RUBINOFF
}

In February 1968, a fateful year perhaps better remembered for its political upheavals, student uprisings, assassinations and the escalation of the Vietnam War than its cinematic achievements, a curiously backward-looking film premiered at the 1968 Cinemanifestatie Festival in Utrecht. ${ }^{1}$ The Chronicle of Anna Magdalena Bach, directed by Jean-Marie Straub and Danièle Huillet, reconstructs the life of Johann Sebastian Bach through an examination of his music and documents, and stars the Dutch harpsichordist Gustav Leonhardt as the composer. ${ }^{2}$ The film, which consists mainly of musical performances of Bach's music, is narrated from the perspective of his second wife, portrayed by Christiane Lang-Drewanz, who recounts the activities of their day-to-day life in Cöthen and Leipzig. ${ }^{3}$ How could an austere film about Bach's life and music, set in a remote eighteenth-century sound- and landscape, have been produced in the midst of the ferment and discontent of the late 1960s?

Not surprisingly, Chronicle did not receive widespread distribution, though it fared respectably for an independently-produced film. Following its premiere, it was viewed at a number of other prestigious European events, including Critics Week at Cannes and festivals in Berlin, Venice, London, and New York, and was awarded several prizes. ${ }^{4}$ Still, Chronicle never found a wide audience. Neither a biopic nor a

A version of this paper was read at the American Society for Eighteenth-Century Studies Annual Meeting, Portland, OR, 28 March 2008. For feedback and suggestions on earlier drafts of this article, I am grateful to the reviewers of this journal, Jed Wentz and Aaron S. Allen. I am especially indebted to Edward H. Tarr and Gustav Leonhardt, who graciously shared their recollections of working with Straub and Huillet with me. The interpretations and opinions expressed in this article, however, represent my own perspective. Translations from Dutch, French and German are mine unless otherwise indicated.

${ }^{1}$ Organized by Hubert Bals, the Cinemanifestatie was held seven times. Bals would later organize the festival Film International, the predecessor of the Rotterdam Film Festival International. Kees Driessen, Canon van de Nederlandse film (Utrecht: Stichting Nederlands Film Festival, 2007), 71.

${ }^{2}$ The Chronicle of Anna Magdalena Bach, directed by Jean-Marie Straub and Danièle Huillet, DVD, 93 mins. (New York: New Yorker Video, 2005). The screenplay was published in German (Frankfurt/Main: Verlag Filmkritik, 1969) and French (Toulouse: Éditions Ombres, 1996). In my discussion of the film, I will refer below to the scene structure outlined in the screenplays rather than the DVD track numbers.

${ }^{3}$ The film shares the title of Esther Meynell's fictional account of Anna Magdalena's life, The Little Chronicle of Anna Magdalena Bach (Boston: E.C. Schirmer, 1934). This book, meant to be read as Anna Magdalena's diary, was first published anonymously in 1925, and again (also anonymously) in German in 1957; it did much to popularize interest in Bach and his music. While Straub has denied that the film was based on this work and objected to its romanticized account of Bach's life, Barton Byg has nonetheless pointed out similarities between the events and dialogue in the film and the book. See Barton Byg, Landscapes of Resistance: The German Films of Danièle Huillet and Fean-Marie Straub (Berkeley and Los Angeles:

University of California Press, 1995), 257.

${ }^{4}$ Richard Roud, Fean-Marie Straub (New York: Viking Press, 1972), 87. Roud (1929-1989) was the first director of the New York Film Festival; a champion of Straub and Huillet's work, he first brought Chronicle to American audiences in the fall of 1968. The film also won the German film critics' prize, and the Grand Prize at the London and Prades festivals of 1968. See Byg, Landscapes of Resistance, 257. 
documentary, the film's generic transgressions stymied critics. Straub-Huillet ${ }^{5}$ employ many documentary-like techniques, such as extended shots during which the camera lingers on musical scores, letters and other manuscripts from Bach's life. Such static camera movement, together with the preponderance of live musical performances and the lack of character development, make for a slowmoving plot. Moreover, few scenes are fully acted out, meaning that Chronicle does not follow the typical Hollywood conventions of the musical biopic, which tend to be romanticized, dramatic interpretations of the composer's life, emphasizing the tragic aspects. ${ }^{6}$ In its resistance to such models, Chronicle exemplifies what Robert Rosenstone has termed an "innovative or experimental" biopic, which "presents a life in the form of a fragmented or a chronological drama rather than a traditional linear story." "

This lack of a conventional narrative structure meant that many disenchanted reviewers for the mainstream press in Germany and the U.S. found the film "deadly dull." Penelope Gilliatt of the New Yorker quipped, "Sometimes I watched the moments when the pretend Bach changed manuals on the harpsichord, and sometimes I fell into things that never get into reviews, like thoughts of dinner, and what to do with your life, and how bitterly cold the air-conditioning can be in America." ${ }^{\circ}$ Following the premiere, a Dutch critic for the Volkskrant, a left-leaning daily, posted a similarly snarky headline: "A soundtrack of Bach does not a film make."

It was not only Chronicle's slow pace that made it lack commercial appeal. Chronicle is also a film oddly out of sync with its own time, in terms of its use of technology, its setting and its topic. It is lowbudget and low-tech: the directors employ black and white film and period costumes while eschewing special effects and even stereophonic sound. ${ }^{11}$ Moreover, with Bach as its rarefied subject, an iconic figure of classical "high art" music, Chronicle seems both disengaged from the pressing social issues of the 1960s and from the musical tastes of that decade's youth culture. This distance from more worldly contemporary concerns was not lost on the avant-garde French director Jean-Luc Godard, who, despite providing financial backing for Chronicle, nevertheless complained about the film's lack of "relevance to contemporary problems." 12 Certainly Godard's own work is far more explicitly ideological; his

\footnotetext{
${ }^{5}$ I will use "Straub-Huillet" hereafter to refer to this team of directors. As Barton Byg has noted, many critics have assumed that Straub is the primary author of their films because of his outspokenness; however, despite the reluctance of Danièle Huillet (1936-2006) to be interviewed, it is clear that she was an equal partner in the production and direction of all their works. See Barton Byg, Landscapes of Resistance: The German Films of Danièle Huillet and Fean-Marie Straub (Berkeley and Los Angeles: University of California Press, 1995), 8-9. A recent documentary on the two directors also makes clear the collaborative nature of their work. See Petro Costa and Thierry Lounas, Où gît votre sourire enfoui? DVD videodisc, 204 mins (Lisbon: Assírio \& Alvim, 2001).

${ }^{6}$ Maureen Turim, "Jean-Marie Straub and Danièle Huillet: Oblique Angles on Film as Ideological Intervention," in New German Filmmakers: From Oberhausen through the 1970s, ed. Klaus Phillips (New York: Frederick Ungar, 1984), 339-40. For a discussion of the musical biopic in regard to filmic representations of Chopin, see Ewa Mazierska, "Multifunctional Chopin: The Representation of Fryderyk Chopin in Polish films," Historical fournal of Film, Radio and Television 24, no. 2: 254-55. ${ }^{7}$ Robert Rosenstone, "In Praise of the Biopic," in Lights, Camera, History: Portraying the Past in Film, ed. Richard Francaviglia and Jerry Rodnitzky (College Station, TX: Texas A\&M University Press, 2007), 15.

${ }^{8}$ Allen Hughes, "Bach as Seen in His $2^{\text {nd }}$ Wife's Memories," New York Times, 20 September 1968, p. 37. For a summary of negative German reviews, see Ursula Böser, The Art of Seeing, the Art of Listening: The Politics of Representation in the Work of Fean-Marie Straub and Danièle Huillet (Frankfurt: Lang, 2004), 15-18; 29-30.

${ }_{9}^{9}$ Penelope Gilliatt, "The Current Cinema: A Report on a Party," New Yorker 44, no. 31 (September 21 1968): 148.

${ }^{10}$ B. J. Bertina, "Geluidsband met Bach is nog geen film," Volkskrant, 5 February 1968, p. 5.

${ }^{11}$ To make an extreme comparison in regard to special effects and production costs, one might recall that Stanley Kubrick's ground-breaking 2001: A Space Odyssey also premiered in 1968.

${ }^{12}$ Roud, Fean-Marie Straub, 71. On Godard's financial backing, see Martin Walsh, The Brechtian Aspect of Radical Cinema, ed. Keith M. Griffiths (London: British Film Institute, 1981), 42; Andi Engel, "Andi Engel Talks to Jean-Marie Straub, and Danièle Huillet is There Too," Enthusiasm 1 (December 1975): 8. Straub received a contribution of 8,000 marks from Godard towards the purchase of film stock for Chronicle. He is acknowledged in the published screenplay and in the opening credits of the film.
} 
controversial films and his outspoken leftist political views would make him a cult hero of the May 1968 movement in Paris. ${ }^{13}$ Indeed, it is striking to contemplate that two of Godard's most politically-engaged films were shown alongside Chronicle in the 1968 festival circuit. ${ }^{14}$ That Godard's films continue to resonate in the collective memories of " $68 \mathrm{ers}$ is indicated by their prominent position on the programs of major 1968 film retrospectives held during the recent fortieth anniversary year, including those of the Film Society of Lincoln Center and the Film Forum in New York, and Cinema '68 in London. Chronicle, however, was conspicuously absent. ${ }^{15}$

Chronicle has occasionally been revived at German avant-garde cinema exhibitions and Bach festivals, and if it remains relatively obscure to the general public, it is known to film studies scholars and Bach aficionados. ${ }^{16}$ The austerity of Straub-Huillet's aesthetic, their economy of means and camera movement, and their artistic single-mindedness have won these directors praise as "filmmaker's filmmakers." ${ }^{\text {" As }}$ such, Chronicle has proven to be a rich text for analysis, particularly from the perspectives of literary and film theory. Maureen Turim, who conducted a frame-by-frame study of the film, argues that Straub and Huillet manipulate classic cinematic codes in Chronicle to construct an alternative narrative, which she associates with minimalism (after Roland Barthes) or "écriture blanche" (after Christian Metz). ${ }^{18}$ Other scholars have analyzed the film's connection to "counter-cinema," Brechtianism and Marxist ideology. ${ }^{19}$

Still, while Chronicle receives a passing mention in recent studies of film music, music scholars have for the most part paid it little attention. ${ }^{20}$ Indeed, the composer biopic is a frequently-maligned genre among musicologists, who tend to be suspicious of such films for their historical inaccuracies, their Romanticized accounts of musicians' lives, and their facile mapping of biographical events to musical ones. ${ }^{21}$ Yet Chronicle cannot so easily be discounted on these grounds. Arguably, it is of interest not only to

\footnotetext{
${ }^{13}$ For a discussion of Godard's political views, including his involvement in the Maoist, anti-Vietnam and student protest movements in France and the U.S., see Richard Brody, Everything is Cinema: The Working Life of Fean-Luc Godard (New York: Metropolitan Books, 2008), 297-364. Although Godard has occasionally employed classical music in his films, he also frequently engages with music and popular culture; his Sympathy for the Devil, filmed in 1968, contains significant footage of the Rolling Stones.

${ }^{14}$ Week-End (1968), a humorous and scathing critique of French bourgeois consumerist society, was also viewed at the Utrecht Cinemanifestatie, Berlin and New York Film Festivals; La Chinoise (1967), which examines the activities of a Maoist cell, was to have been shown at Cannes, until Godard and other directors, in solidarity with striking students and workers across France, forced the cancellation of the festival. See Brody, Everything is Cinema, 330-32.

${ }^{15}$ A.O. Scott, “The Spirit of '68," New York Times, April 27, 2008; www.1968.org.uk (Accessed 13 May 2008). The Lincoln Center festival showed another Straub-Huillet film, The Bridegroom, the Comedienne and the Pimp (Der Bräutigam, die Komödiantin und der Zuhälter).

${ }^{16}$ In part, this is due to the limited circulation of Straub-Huillet's films. Until recently, Chronicle, released in 2005 on DVD by New Yorker Video, was the only one of Straub-Huillet's films to be widely available in the U.S.

${ }^{17}$ James Franklin, New German Cinema (Boston: Twayne Publishers, 1983 ), 77.

${ }^{18}$ Maureen Turim, "Écriture blanche: The Ordering of the Filmic Text in The Chronicle of Anna Magdalena Bach," Purdue University Film Studies Annual (1976): 177-92.

${ }^{19}$ Scholarly exegeses of Chronicle include: Bruce L. Jenkins, "The Counter-Cinemas of Straub/Huillet and Robbe-Grillet," Purdue University Film Studies Annual (1976): 144-56; Martin Walsh, The Brechtian Aspect of Radical Cinema, edited by Keith M. Griffiths (London: BFI, 1981); Byg, Landscapes of Resistance, 51-70; Böser, The Art of Seeing.

${ }^{20}$ The film is discussed briefly in a few recent monographs on film music, including that of Claudia Gorbman, who remarks that the centrality of musical performances to Chronicle disrupts narrative continuity, thus proving the exception to her rule that music is usually subordinate and serves primarily to underscore the storyline. See Claudia Gorbman, Unheard Melodies: Narrative Film Music (Bloomington and Indianapolis: Indiana University Press, 1987), 13-14. Mervyn Cooke also includes Chronicle in the context of a chapter on the use of classical music in film. See Mervyn Cooke, A History of Film Music (Cambridge: Cambridge University Press, 2008), 448.

${ }^{21}$ See, for example, the following articles from the roundtable discussion of music, musicology and film in the Summer 1997 issue of Musical Quarterly, in which these and other related issues are addressed: Robert L. Marshall, "Film as Musicology: 'Amadeus,"” Musical Quarterly 81, no. 2 (Summer 1997): 173-79; Ellen T. Harris, “Twentieth-Century Farinelli," Musical Quarterly 81, No. 2 (Summer 1997): 180-189; Lewis Lockwood, “Film Biography as Travesty: 'Immortal Beloved' and
} 
film scholars, but also to historical performers and music historians interested in the development of the twentieth-century Early Music movement. As such, I will attempt to give Chronicle a "musicological" reading here, considering the film not just as a work of art, or as a text to be deciphered, but rather as an historical document - a document not unlike the Bach manuscripts and other remnants of the composer's life scrutinized by Straub-Huillet's camera. What does the film tell us, for example, about Bach performance practice in 1968? How is the eighteenth century-and specifically, the music of the eighteenth century-represented in this film, and for what purpose? Moreover, what could an analysis of the film contribute to the historiography of the Early Music movement, and to our contemporary understanding of post-World War II Bach performance practice and reception?

Created in the late 1960s, at what I argue was a transitional moment in the Early Music revival, Straub-Huillet's film brings together some of the most prominent historical performers of the time surrounding the music of a key figure, J.S. Bach. In their attempt to recreate the life and music of this composer on the screen, the directors and performers grapple with issues fundamental to the project of historical revival: authenticity in musical performance, the relationship of the artist's biography to the interpretation of the work, and the relationship between music and political ideology. Chronicle, as a product of these negotiations, presented an influential model of how to perform Baroque music "authentically," one which had a lasting impact on the post-war Early Music movement. An important film from historical and aesthetic standpoints, Chronicle also articulates a powerful political message relevant to post-war European society: Bach's life and works become an allegory, presenting a critique of fascist and capitalist exploitation of the artist. As such, Chronicle is more than an antiquarian film about the eighteenth century: it is just as much a product of 1968 as the work of Godard, Bertolucci, and other figures associated with the cinematic avant-garde of that period.

\section{Performing Bach “Authentically” on Film}

In the opening minutes of Chronicle, the credits roll silently across the screen in white typescript on a stark black background. Suddenly, the audience is confronted by sound: the first movement of the Brandenburg Concerto no. 5, specifically the final instrumental tutti before the beginning of the harpsichord cadenza (mm. 147-154). The credits give way, towards the end of the cadenza, to a shot of the back of a bewigged Gustav Leonhardt, whose nimble hands move rhythmically across the coupled manuals of a harpsichord (the upper manual might appear — to a viewer unfamiliar with harpsichord mechanics—-to be moving of its own ghostly accord). Gradually the camera tracks backward to show the other musicians, also in wigs and costume, one holding a violin (sans chin and shoulder rest), the other a wooden transverse (not Boehm-system) flute. ${ }^{22}$ For an audience in 1968, this Brandenburg Concerto performance would have been at once recognizable music, yet also jarringly unfamiliar-sounding on period instruments; the foreignness of period costumes and wigs would arouse further curiosity (see VIDEO EXAMPLE 1). ${ }^{23}$

Beethoven,” Musical Quarterly, Vol. 81, No. 2 (Summer 1997): 190-198; Jeffrey Kallberg, “Nocturnal Thoughts on 'Impromptu," Musical Quarterly, Vol. 81, No. 2 (Summer 1997): 199-203.

${ }^{22}$ Camera indications for each shot are listed in the published screenplay. See, for example, Danièle Huillet and Jean-Marie Straub, Chronique d'Anna Magdalena Bach (Toulouse: Éditions Ombres, 1996), 24. The directors sometimes employ panning shots (for example in shooting Bach documents), but elsewhere they usually employ tracking shots to record ensembles.

${ }^{23}$ Period-instrument performances of the Brandenburg Concerti in the late 1960s were still not common, though there were at least three commercially-available recordings at the time, including August Wenzinger's 1953 recording with the Schola Cantorum Basiliensis, and recordings with Nikolaus Harnoncourt and Concentus Musicus Wien (1964), and Collegium Aureum (1965). See Dorottya Fabian, Bach Performance Practice, 1945-1975: A Comprehensive Review of Sound Recordings and 


\section{Video Example 1}

Accessible at: http://dx.doi.org/10.3998/mp.9460447.0005.103

That the viewer-listener is transported to an alien eighteenth-century land- and soundscape is not just a cinematic exercise in imaginary time-travel. Through this opening sequence, which sets the tone for the entire film, Straub-Huillet make a strong aesthetic statement, placing Chronicle squarely at the center of the so-called "authenticity debates" surrounding the field of Baroque performance practice. These debates had been raging in Germany, England and America from the 1950s on as performers, musicologists and critics alike were asking essential questions about the relevance of historical inquiry to musical interpretation. ${ }^{24}$ What, for example, might it mean to perform music "authentically"? To what extent was it possible to recreate the conditions surrounding the original performance of a musical work? Could one ever truly establish the composer's intentions? And was this even desirable?25

In Chronicle, Straub and Huillet convey their position on authenticity in their meticulous attention to historical minutiae, both visual and aural, and in the details of the film's production. The film was shot entirely on location at various "Bach sites" in West Germany and in the German Democratic Republic, including Eisenach, Arnstadt, Erfurt, Weimar, Dresden, Leipzig, and Mülhausen. Where one significant location no longer existed - the St. Thomas School in Leipzig, which was torn down in 1902—StraubHuillet accentuate its very absence through cinematographic artifice: during a performance of the cantata "Preise dein Glücke, gesegnetes Sachsen", BWV 215 (shot 57), they show instead a rear projection of the building's image, with a shot of a burning torch on the left, and the composer conducting from the harpsichord (see FIGURE 1). ${ }^{26}$ Most of the screenplay's text is taken verbatim from Bach documents, such as his letters, manuscripts, and necrology; while conducting research for the film in the late 1950s, Straub and Huillet traveled extensively throughout Germany in order to view and copy these documents themselves. ${ }^{27}$ The camera often lingers on shots of these texts and music manuscripts as Bach's music plays in the background, as in shots 9 through 32, which are accompanied by the Largo of the Trio Sonata No. 2 in C Minor for Organ, BWV 526. With only a few exceptions (Bach's rebuke by the Leipzig town council, shot 44, and Johann Elias Bach's announcement of the vice-rector's suicide, shot 88), very little of Bach's

\footnotetext{
Literature (Aldershot, UK and Burlington, VT: Ashgate, 2003), 65-68.

${ }^{24}$ A position against historical performance practice was articulated perhaps most notoriously in 1951 by Theodor W. Adorno in "Bach Defended against His Devotees," in Prisms, trans. Samuel and Shierry Weber (London: Spearman, 1967), 133-46.

${ }^{25}$ For a summary of these debates, see Fabian, Bach Performance Practice, 1945-1975, 1-28. In English-language publications, discourse became particularly heated in the mid-1980s, and is still ongoing. See, for example, Laurence Dreyfus, "Early Music Defended against Its Devotees: A Theory of Historical Performance in the Twentieth Century," Musical Quarterly 69, no. 3 (Summer 1983): 297-322; Joseph Kerman, Contemplating Music: Challenges to Musicology (Cambridge, MA: Harvard University Press, 1985), 182-217; Nicholas Kenyon, ed., Authenticity and Early Music: A Symposium (Oxford: Oxford University Press, 1988); Joseph Kerman, Laurence Dreyfus, Joshua Kosman, John Rockwell, Ellen Rosand, Richard Taruskin, and Nicholas McGegan, “The Early Music Debate: Ancients, Moderns, Postmoderns," Fournal of Musicology X, no. 1 (Winter 1992): 113-130; Michelle Dulak, “The Quiet Metamorphosis of 'Early Music," repercussions 2, no. 2 (Fall 1993): 3161; Richard Taruskin, Text and Act: Essays on Music and Performance (New York and Oxford: Oxford Univ. Press, 1995); Peter Kivy, Authenticities: Philosophical Reflections on Musical Performance (Ithaca and London: Cornell University Press, 1995); John Butt, Playing with History: The Historical Approach to Musical Performance (Cambridge: Cambridge University Press, 2002); Bruce Haynes, The End of Early Music: A Period Performer's History of Music for the Twenty-First Century (Oxford and New York: Oxford University Press, 2007).

${ }^{26}$ See also note 45 below for further discussion of this scene.

${ }^{27}$ Engel, "Andi Engel Talks to Jean-Marie Straub," 1. Many of the Bach documents employed in the film are included in English translation in The New Bach Reader: A Life of Fohann Sebastian Bach in Letters and Documents, ed. Hans T. David and Arthur Mendel, revised and enlarged by Christoph Wolff (New York: W.W. Norton, 1998).
} 


\section{Music and Politics Winter 2011}

life is dramatized or acted out in the conventional sense. Ironically, it is the presence of the Bach locations and documents in the film that foregrounds the very fact that there is no surviving "chronicle" of Bach's life: confronted by his monumental musical achievements, we are forced to piece together our understanding of this complex musician, composer and artist from fragmentary sources of information.

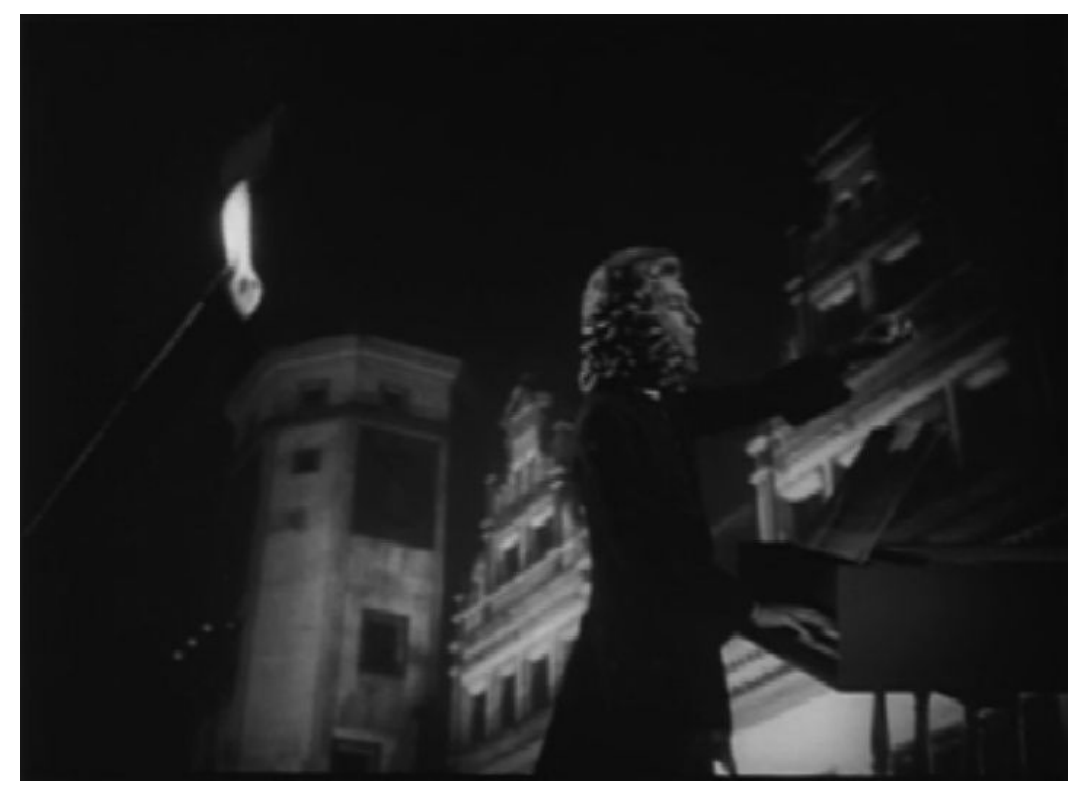

Figure 1. Gustav Leonhardt as J.S. Bach, shown conducting with rear projection of the St. Thomas School (shot 57).

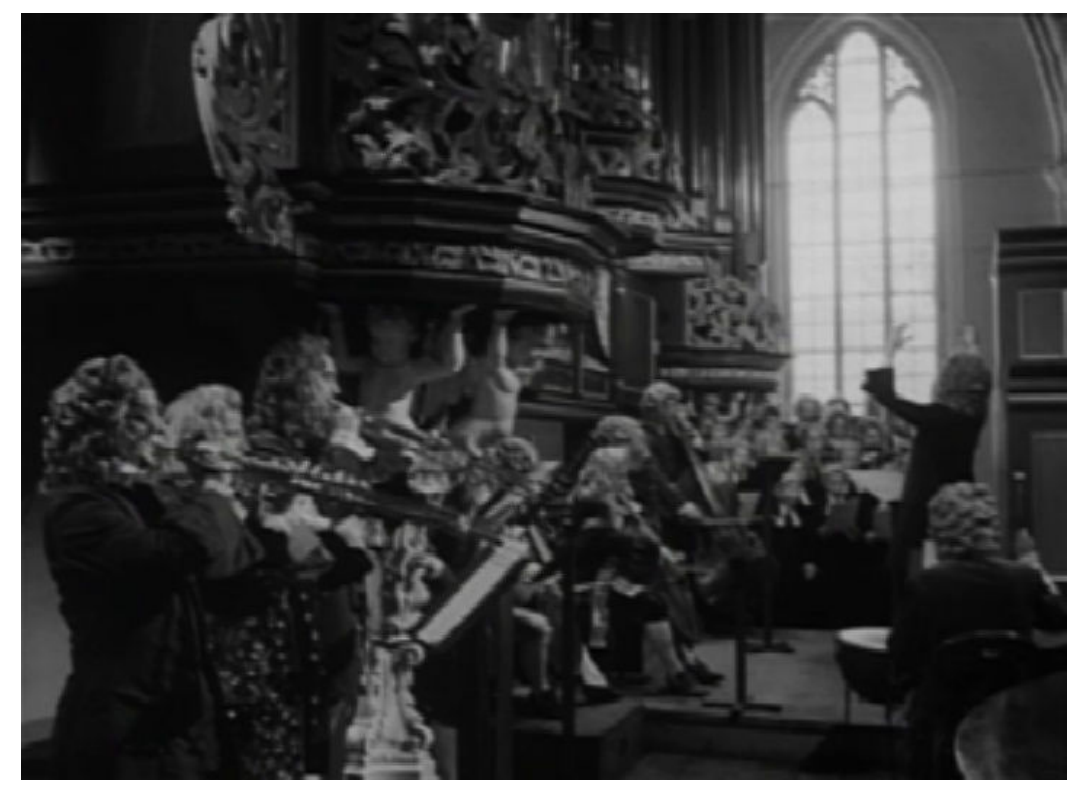

Figure 2. Close-up showing period instruments (shot 33). 
In an interview with Andi Engel, Straub discussed the documentary-like aspects of his approach to historical fidelity, frequently stressing the labor and extensive research involved in the film's production. ${ }^{28}$ He noted that the musicians and other characters in Chronicle are costumed in wigs, including the choristers who portray the young boys of the St. Thomas School, period jackets and dresses (many of which they designed themselves, "after old prints"), buckled shoes, and even spectacles, which they had specially made according to the performers' prescriptions. ${ }^{29}$

Such a documentary approach also extends to the use of period instruments in Chronicle. Indeed, it is one of the earliest films to employ original instruments or copies on screen, a fact that warranted it a mention in Harry Haskell's account of the historical performance movement as an indication of "early music's gradual absorption into twentieth-century mass culture." ${ }^{30}$ While it might be a stretch to suggest that a relatively little-known independent film is representative of "mass culture," it is certainly arguable that the use of harpsichords, viola da gambas, Baroque oboes and other instruments from Bach's time on screen made them more widely known to the public. If record collectors might have been familiar with the sounds of period instruments, for example by listening to August Wenzinger, Gustav Leonhardt or Nikolaus Harnoncourt's pioneering Bach recordings, Straub-Huillet were providing their audience here with both an aural and a visual component. Straub-Huillet's camera at times focuses on the instruments for extended periods, as in the opening Brandenburg performance described above, and also during a performance of the Magnificat in D Major, BWV 243 (no. 11, "Sicut locutus est", shot 33). Here, the camera gradually tracks from a shot of the organ continuo player, to show two violoncellists playing without endpins, a Baroque bassoon, and three valveless trumpets; Bach, again with his back to the camera, is shown directing the ensemble (see FIGURE 2). The camera's attention to these instruments indicates that they, too, are an essential part of the cinematographic spectacle of historical reenactment and-more importantly—part of Straub-Huillet's authenticity aesthetic.

Straub discussed the specifics of the instruments used in Chronicle on several occasions in interviews with the press, demonstrating a remarkable familiarity with aspects of eighteenth-century performance practice for a non-musician. As he remarked to Andi Engel,

There are some original instruments among the ones we used, the oboes are all original. There are also copies, the violins for instance, they used to play standing, which is not done any more, and the violinists played without the chin-support. No, we kept a bloody good eye on those details. $^{31}$

Even more striking, Straub takes credit for having spurred the musicians towards greater fidelity to the performing forces and instruments of Bach's time. In a 1968 interview in the German periodical Film, Straub noted the difficulty of finding a choir willing to perform Bach's cantatas with only three boys on each part. ${ }^{32}$ When told that natural trumpet playing was not possible in the modern day, Straub nevertheless insisted upon it, and remarked that, "In the meantime they've managed it, not without some

\footnotetext{
${ }^{28}$ Engel, “Andi Engel Talks to Jean-Marie Straub,” 1. See also below for Straub-Huillet's battles with German film subsidy agencies to obtain financing for Chronicle.

${ }^{29}$ Engel, "Andi Engel Talks to Jean-Marie Straub," 9.

${ }^{30}$ Harry Haskell, The Early Music Revival: A History, $2^{\text {nd }}$ ed. (Mineola, NY: Dover, 1996), 124, 158.

${ }^{31}$ Engel, "Andi Engel Talks to Jean-Marie Straub," 9.

${ }^{32}$ According to one interpretation of the "Short But Most Necessary Draft for a Well-Appointed Church Music," where Bach seems to specify that a choir should have twelve members. This document is included in The New Bach Reader, 145-51. More recently, scholars such as Joshua Rifkin and Andrew Parrott have argued for a different interpretation of this document, suggesting that Bach in fact used one voice per part in his cantatas. See Andrew Parrott, The Essential Bach Choir (Woodbridge, UK: Boydell Press, 2000).
} 
impetus from my film project." 33 While some of Straub's assertions might have been exaggerated, ${ }^{34}$ they do suggest Straub's realization that claims to authenticity would have resonance for an educated sector of his audience.

Not only did Straub-Huillet go to great lengths to employ period instruments in the film, but they were also extremely selective in their choice of musicians to appear on the screen. They engaged professional performers rather than actors to portray Bach and other figures, and these musicians were actually playing during filming. Specifically the directors chose three leading figures at the vanguard of the post-war historical performance movement: Gustav Leonhardt, who like Bach himself performs in Chronicle on harpsichord, organ and as conductor; August Wenzinger, who directs the Schola Cantorum Basiliensis; and Nikolaus Harnoncourt, who appears on screen as Bach's patron, Prince Leopold of Cöthen, performing on viola da gamba and with his ensemble, Concentus Musicus Wien, as his "court orchestra." ${ }^{35}$ Leonhardt, Wenzinger and Harnoncourt were among the first musicians to attempt to put an understanding of Baroque ornamentation, fingerings and bowings, tempo, rhythm and performing forces into practice, as gleaned from seventeenth- and eighteenth-century treatises; in the 1950s, they were also releasing some of the first period instrument recordings of Bach's music. Through such recordings, interest in historical performance was spreading beyond specialists more widely to the general public. As Straub and Huillet relate in a 1995 interview, they had themselves first discovered Leonhardt some ten years before making Chronicle by listening to one of his Bach LPs, which they had borrowed from a friend. ${ }^{36}$

Prior to World War II, historical performers were at the fringes of classical music culture: critics and "mainstream" professional musicians sometimes considered them antiquarians, dilettantes or regressive for rejecting more "technologically advanced" modern instruments. ${ }^{37}$ However, by the mid-1960s Leonhardt and Harnoncourt were gaining recognition as Bach interpreters through their recordings for such major labels as Deutsche Harmonia Mundi and Telefunken's Das Alte Werk series. ${ }^{38}$ Indeed, many accounts of the twentieth-century Early Music movement identify the 1960s as a watershed moment, during which

\footnotetext{
${ }^{33}$ Joachim Wolf, Interview with Jean-Marie Straub, Film (April 1968): 25. The English translation is by Byg, Landscapes of Resistance, 55. Straub and Huillet made similar comments about the lack of availability of period instrument recordings in a 1995 interview in Cahiers du Cinéma. As Huillet put it, “... personne n'avait encore joué les cantates et dirigé des choeurs de garçons de cette façon-là" (Nobody had yet played the cantatas and directed boys' choirs in this manner). Jean-Claude Biette, "Bach/Schonberg; Entretien avec Jean-Marie Straub et Danièle Huillet," Cahiers du Cinéma (November 1995): 47.

${ }^{34}$ Edward H. Tarr notes that (largely unsuccessful) experiments with natural trumpets had begun as early as 1931 by the Kammermusikkreis Scheck-Wenzinger, but that he, in collaboration with Meinl \& Lauber and Rainer Egger, developed a "Baroque trumpet" based on several historical models in 1967. See Edward H. Tarr, "Western Trumpet," In Grove Music Online, Oxford Music Online, http://www.oxfordmusiconline.com/subscriber/article/grove/music/49912 (Accessed 23 March 2009). It is not clear whether or not Straub and Huillet were the impetus for developing this instrument, though the year of its production does correspond with the year Chronicle was filmed.

${ }^{35}$ The casting of Harnoncourt here is possibly a humorous reference to his actual noble birth: his full name is Count Nikolaus de la Fontaine und d'Harnoncourt-Unverzagt, and he is referred to as a count in the published screenplay's cast listing. See Chronik der Anna Magdalena Bach (Frankfurt/Main: Verlag Filmkritik, 1969), 5. August Wenzinger directs the Schola Cantorum Basiliensis, another pioneering period instrument ensemble, which here represents Bach's church orchestra in Leipzig. Bob van Asperen, harpsichordist and former Leonhardt student, also makes a cameo appearance in Chronicle as Johann Elias Bach.

${ }^{36}$ Biette, "Entretien avec Jean-Marie Straub et Danièle Huillet," 47.

${ }^{37}$ For a summary of such criticism from composers and conductors, see, for example, Colin Lawson and Robin Stowell, The Historical Performance of Music: An Introduction (Cambridge: Cambridge University Press, 1999), 11-12.

${ }^{38}$ Prior to the making of Chronicle, Harnoncourt had recorded the Brandenburg Concertos (1964) and orchestral suites (1966), and the St. Fohn Passion (1965) for Telefunken. Leonhardt had recorded the Brandenburg Concertos with Collegium Aureum on Harmonia Mundi in 1965; he began recording chamber works Telefunken in the early 1960s. See Fabian, Bach Performance Practice, 1945-1975, 39-40.
} 
historical performers were attempting to achieve parity in playing standards with other classical musicians, and making a "push toward professionalism." ${ }^{39}$ The production of Chronicle contributes to our understanding of why historical instruments were adopted on a more widespread basis during this particular period. The film demonstrated that it was possible to record large-scale, complex works by Bach on original instruments or copies-in many instances, in one take-suggesting that historical performance was moving beyond an experimental phase into a viable artistic and commercial enterprise. It also demonstrated that historical performers could take on ever more ambitious projects at a high performance level. In 1971, only a few years after Chronicle's premiere, Telefunken and the record producer Wolf Erichson again paired Harnoncourt and Leonhardt as conductors for their Bach cantata cycle, the first complete set to be recorded on period instruments. ${ }^{40}$ Straub-Huillet's use of period instruments here was at once ground-breaking in the film world, but at the same time it also accorded the Early Music movement_and these particular performers-prestige and recognition by association with the cinematic avant-garde.

Chronicle thus marks an important milestone because of the directors' and the performers' particular approach to historical verisimilitude. Sympathetic film critics have tended to emphasize the "authentistic" approach of Straub and Huillet as one of the validating aspects of their directing and as a particular sign of their craftsmanship and attention to detail. ${ }^{41}$ Yet the use of period instruments and costumes form but one component of this authenticity aesthetic. They also employ direct sound to record complete musical performances, instead of post-synchronizing the soundtrack or splicing out errors, and they use one microphone for most performances, even though multi-track and stereophonic recordings were by then the industry standard in high fidelity. ${ }^{42}$ For Straub-Huillet, direct sound was both an aesthetic and an ideological choice in response to the dominant film industry practice of dubbing:

Straub: The dubbed cinema is the cinema of lies, mental laziness, and violence, because it gives no space to the viewer and makes him still more deaf and insensitive. In Italy, every day the people are becoming more deaf at a terrifying rate.

Huillet: The thing is still sadder when you think that it's in Italy that, in a certain sense, Western music, polyphony, was born. ${ }^{43}$

\footnotetext{
${ }^{39}$ Kay Kaufman Shelemay, "Toward an Ethnomusicology of the Early Music Movement: Thoughts on Bridging Disciplines and Musical Worlds," Ethnomusicology 45, no. 1 (Winter 2001): 11. Other writers who pinpoint the 1960s' importance to the historical performance movement include Laurence Dreyfus, "Early Music Defended against Its Devotees: A Theory of Historical Performance in the Twentieth Century," Musical Quarterly LXIX, no. 3 (Summer 1983): 310, 320; Joel Cohen and Herb Snitzer, Reprise: The Extraordinary Revival of Early Music (Boston: Little, Brown, 1985), 61; Nicholas Kenyon, "Introduction: Some Issues and Questions", in Authenticity and Early Music: A Symposium (Oxford and New York: Oxford University Press, 1988), 2-3; Robert Philip, Performing Music in the Age of Recording (New Haven and London: Oxford University Press, 2004), 204; Bruce Haynes, The End of Early Music (Oxford and New York: Oxford University Press, 2007), 40-41.

${ }^{40}$ The Bach cantata project, while it marked the beginning of a longstanding collaboration, was not Leonhardt's first production with Erichson. In Fall 1962, he had produced a recording of Bach's Concerto in A Minor for Four Harpsichords, BWV 1065 with the Leonhardt Consort. For more on Leonhardt and Erichson's relationship, see Thomas Otto und Stefan Piendl, Erst mal schön ins Horn tuten: Erinnerungen eines Schallplattenproduzenten (Regensburg: Con Brio, 2007$), 113$.

Leonhardt's appearance in Chronicle is specifically mentioned on page 108.

${ }^{41}$ See, for example, Rosalind Delmar, “Chronik der Anna Magdalena Bach,” Monthly Film Bulletin 37 no. $432 / 443$ (1970): 96; Susan Dermody, "Jean-Marie Straub and Danièle Huillet: The Politics of Film Practice," Cinema Papers 3, no. 10 (September 1976): 130; Böser, The Art of Seeing, 31.

${ }^{42}$ As Straub tellingly related in a 1995 interview, "We don't want any stereo in our films. Something needs to separate us from Godard." Biette, "Entretien avec Jean-Marie Straub et Danièle Huillet," 49.

43 "Direct Sound: An Interview with Jean-Marie Straub and Danièle Huillet," trans. Bill Kavaler, in Film Sound: Theory and Practice, edited by Elisabeth Weis and John Belton (New York: Columbia University Press, 1985), 150. The editors note that
} 
The purpose of direct sound in Chronicle was to counteract the artificiality of recording devices, technologies that would be anachronistic in a film about eighteenth-century music. ${ }^{44}$ For the musicians, however, Straub's insistence on recording in complete takes was stressful, particularly considering the fact that many were performing on unfamiliar instruments. ${ }^{45}$ Mistakes are at times clearly audible, and the microphone placement makes for an uneven sound quality.

Film critics have often commented on the resultant aural experience of listening to Chronicle. For Rosalind Delmar, "Even a composition as well known as the fifth Brandenburg Concerto, which opens the film, acquires a new freshness, partly due to the placing of the microphone (near the harpsichord, which Bach is playing)." Maureen Turim has also remarked that the lack of stereo sound is flat, which mirrors the two-dimensionality of the Bach documents shown on the screen and highlights for the viewers the fact that they are watching a film and not a documentary or live performance, forcing a confrontation with the very artificiality of historical reconstruction. She remarks that, "The music is not so much enchanting as it is intriguing, and (despite the flatness of the filmic sound or, perhaps, because of it) something new is heard." ${ }^{47}$ But critics in the mainstream press have often been less sanguine. Friedrich Hommel, in a 1968 review for Film, found that the poor recording quality was irritating, making the film into a series of "static tableaus whose vaguely flat effect gave the impression of sonic postcards." ${ }^{48}$ David Oestreich, reviewing Chronicle for the New York Times after a showing in 2000, likewise felt the monaural miking indicative of the film's poor sound quality, complaining that, "gaps in the antiphonal portions of the great opening chorus of the 'St. Matthew Passion' make for painful listening even for someone used to all manner of surface noise on recordings." That the sound quality means that "something new is heard" even when the viewer is presented with Bach's most familiar works; that one is not "enchanted" by Bach's music but rather "intrigued" by it; and-more importantly in the case of Oestreich—that the film disrupted his enjoyment of one of Bach's great masterworks is telling and, I would argue, precisely the directors' intent.

The critical reception of Chronicle makes it clear that direct sound, period instruments and costumes are not merely used in the film for the purpose of "authenticity" for its own sake. They are also used for their disruptive effect: in 1968, audiences were accustomed to hearing Bach's keyboard works played on a modern piano, the Passions performed with large choirs of singers, and the Brandenburg Concerti played with a large orchestra. Similarly, audiophiles expected to hear crystal clear, stereo recordings on their home hi-fi systems-recordings which are meant to present a "perfect" performance of the great composer's "timeless masterpiece." The soundtrack of Chronicle thus reflects a cinéma vérité aesthetic in that it

\footnotetext{
this interview was originally published in Cahiers du Cinéma, though no further bibliographic information is given.

References to Italy in the above passage suggest that the interview took place after Straub and Huillet moved to Rome in 1969.

${ }^{44}$ That period instrument performers are overly-reliant on editing technology to splice together performances has been a longstanding critical complaint. For a summary, see Robert Philip, Performing Music in the Age of Recording (New Haven, CT: Yale University Press, 2004), 224-25 and Fabian, Bach Performance Practice, 1945-1975, 39-40.

${ }^{45}$ As the trumpet player Edward H. Tarr, who performs in Chronicle as Bach's principal trumpeter Gottfried Reiche, related, “...I can tell you that the entire recording situation was nerve-racking, since Straub did not believe in splicing...and insisted that if there were any mistakes, we had to go back to the beginning of a given number. We began that cantata [BWV 215] chorus over 20 times! Either somebody, including us trumpeters, made a 'clam', or still more often the chorus got out of tune. It did not help us psychologically to know that this was the last work that Gottfried Reiche played, for he collapsed in the street and died the following day back in 1734...". Edward H. Tarr, personal communication, 25 March, 2009.

${ }^{46}$ Delmar, "Chronik der Anna Magdalena Bach."

${ }^{47}$ Turim, "Jean-Marie Straub and Danièle Huillet," 340.

${ }^{48}$ Friedrich Hommel, "Le Martyr de Saint-Jean-Sébastien: Anmerkungen eines Musikkritikers zu Straubs Chronik der Anna Magdalena Bach," Film (May 1968): 31.

${ }^{49}$ James Oestreich, “Critic's Notebook: With Bach as Point and Counterpoint,” New York Times, 1 April, 2000, B7.
} 
represents the sound production as it actually happened during filming. Yet, while the soundtrack is meant to capture the sounds of the performing forces of Bach's time, it does not attempt to represent the vantage point of an idealized listener to the music.

In sum, live sound, with its intermittent audio quality, and antiquated instruments, with their uneven tone and intonation (at least, as played by the pioneering historical performers of the 1960s) disassociate the listener from the Romantic sound world. We are not meant to enjoy Bach's music here in a usual-sensual-sense; we are not meant to listen passively, relax, or derive pleasure from the performances in Chronicle.

\section{Whither Authenticity?}

In addition to the sound quality of the audio recording, critics often comment about several curious violations of historical verisimilitude in the film, many of which Straub himself has acknowledged as intentional. ${ }^{50}$ Straub-Huillet's Bach does not age, for example, and Leonhardt himself, with his slim build, does not at all resemble the portly Bach (at least, as he is represented in the well-known 1748 portrait by Elias Gottlob Haussmann). Leonhardt's speech inflections are also un-Bachian, in that his heavilyaccented German marks him as a non-native speaker of the language. ${ }^{51}$

It is not only that Leonhardt does not share a physical resemblance with Bach. He, along with Christiane Lang-Drewanz, also makes no attempt to act on the screen, at least in the conventional sense of the word. Johann Sebastian and Anna Magdalena simply recite the texts and documents from Bach's life on camera at a brisk pace and with minimal expressive nuance. Likewise, potentially dramatic events, such as the deaths of several of Bach's children, or the vice-rector's suicide, are reported with blunt matter-offactness. Critics have sometimes assumed that the lifeless delivery of the script resulted from the use of non-professional actors. ${ }^{52}$ But as contemporary documentary footage from the Dutch public television station VARA demonstrates, this affectless delivery of the script was carefully cultivated during filming. ${ }^{53}$ In the passage below which I transcribed from the documentary, Gustav Leonhardt reads Bach's notes on basso continuo playing during the filming of shot $70,{ }^{54}$ and is constantly reprimanded by Straub for doing so with too much expression (See VIDEO EXAMPLE 2):

\footnotetext{
${ }^{50}$ Jean-Marie Straub, “Sur Chronique d’Anna Magdalena Bach,” Cahiers du cinéma 193 (September 1967): 58. This essay was reproduced in the introduction to the French script of Chronicle (Toulouse: Editions Ombres, 1996), 9-18. Danièle Huillet remarks in a footnote that this essay originated as an interview, conducted in German with Enno Patalas, and edited and printed in the November 1966 issue of Filmkritik (Munich). The essay's goal was to help raise funds for the film's production. ${ }^{51} \mathrm{I}$ am grateful to Jed Wentz for pointing this out to me. As Byg notes, Straub-Huillet frequently use non-native speakers in their films as an alienation effect and to highlight the act of filmmaking as a form of translation. See Byg, Landscapes of Resistance, 199-214. In the case of Chronicle, the specific function of this alienation effect-and of Leonhardt's nonGermanness-will be clarified below.

${ }^{52}$ Penelope Gilliat, the New Yorker critic, remarks thusly: "Considering the stark pedantry of the film, is there a source for making Anna Magdalena so draggy? I suspect the film of contributing to that. Bach himself is no ball of fun, though an arctic smile plays round his lips when he gets to a pleasing bit in his own music.” James Oestreich of the New York Times was similarly unimpressed, noting, "That the gaunt Mr. Leonhardt looks undernourished in the role is the least of the problems. In its dead-truly dead-earnestness, the film joins the ranks of cinematic howlers based on composers' biographies." ${ }^{53}$ This Dutch-language documentary from 1968 was restored by the Nederlands Instituut voor Beeld en Geluid and is included as the bonus "Making of" Featurette with the New Yorker Films DVD. The VARA, Vereniging van Arbeiders Radio-Amateurs, or Society of Workers' Radio Amateurs, was the broadcasting arm of the Social Democratic Workers Party (SDAP).

${ }^{54}$ The shot is referred to as scene 106 in the documentary, but I have adjusted the numbering to reflect the published screenplay.
} 


\section{Video Example 2}

Accessible at: http://dx.doi.org/10.3998/mp.9460447.0005.103

Narrator: The central figure is Gustav Leonhardt, who personifies Bach. Straub does not want to turn him into an actor. He does not want any accents or expression in the text. Once again, he aims at complete authenticity [echtheid].

Straub: Okay, once again. At the beginning, you were...You were more free in the beginning.

Leonhardt: Well, it's hard...

Straub: Action. [bitte]

Leonhardt: It is also called "bassus continuus," or with the Italian ending...

Straub: Your hand there...that definitely has to stay like that...

Leonhardt: Which one?

Straub: Your left.

Leonhardt: My left.

Straub: And your right, too.

Leonhardt: [beginning again] It is also called "bassus continuus," or with the Italian ending "basso continuo," because it is played continuously, while the other voices pause here and there. Today, however, this bass is often..."

Straub: Too many... "Pause here and there", you could tell that you tried something ... naturalistic...somehow...you tried to...Yes.

Leonhardt: No, I didn't try something naturalistic.

Straub: The ... my impression is ... I had the impression that you've been wanting to give us the impression you do this naturally somehow.

Leonhardt: No.

Straub: [laughs] Action. [bitte]

Leonhardt: It is also called "bassus continuus," or with the Italian ending "basso continuo," because it is played continuously, while the other voices pause here and there. Today, however, this bass is often found to pause quite frequently, especially in artfully arranged pieces.

Straub: This can become almost ironic. It can become ... a mixture of defiance and irony.

Leonhardt: [beginning again] It is also called "bassus continuus," or with the Italian ending "basso continuo," because it is plays continuously, while the other voices pause here and there. Today, however, this bass is often found to pause quite frequently, especially in artfully arranged pieces.

[voice off-screen]: Very good.

Straub: Yes. Thank you. Keep this. ${ }^{55}$

\footnotetext{
${ }^{55}$ This section occurs at 4:03 in the documentary. The English translation of the original spoken Dutch and German is that provided in the subtitles. I have provided the original language in square brackets where it may clarify the meaning of the text.
} 
In the above excerpt, we observe Straub explicitly instructing Leonhardt to efface the emotion and inflection from his speech. Straub likewise remarked in a 1967 essay in Cahiers du cinéma that, "Our work during the editing process consisted principally of erasing all trace of intentions, of expression." ${ }^{56}$ The directors also avoided filming the actors head-on, choosing instead to film them from afar, from behind, or at an angle: in this way, the focus on facial expressions is suppressed, thwarting the viewer's attempts to empathize or emote with the actor.

The restraint and lack of emoting in the acting performances in Chronicle carries over to the musical performances. They also tend to be devoid of interpretive inflection: the musicians, like the actors, give a "straight" reading of the texts. Tempi are brisk and are strictly adhered to throughout a movement, and there is little flexibility or rubato in the playing, particularly in the bass recitative of the cantata Der zufriedengestellte Aolus, BWV 205 (shot 37), and in the overture to the St. Matthew Passion, BWV 244 (shot 42; see VIDEO EXAMPLE 3). These performances give the impression that the musicians are likewise trying to avoid imposing an interpretation on the score. ${ }^{57}$

\section{Video Example 3}

Accessible at: $\underline{\text { http://dx.doi.org/10.3998/mp.9460447.0005.103 }}$

In this regard, critical writing about the film resonates strongly with musicological criticism of period instrument recordings from the late 1960s onward. Paul Henry Lang, in a 1972 editorial in Musical Quarterly, complained that performance practice scholarship was producing performances that were "cool, depersonalized, [and] meticulous," and that a recent Harnoncourt recording of the St. Matthew Passion was "timid and pale," and "uniformly colorless and subdued." ${ }^{28}$ Even critics sympathetic to historical performance, such as Laurence Dreyfus, Susan McClary and Richard Taruskin, have lodged similar complaints about overly literalistic or mechanical period-instrument playing. ${ }^{59}$ For Taruskin, the crux of his critique comes from two angles: that "letting the music speak for itself" makes "authentistic performances" not true to the past, but actually modernist; and that the tempo inflexibility in these performances has more in common with Stravinsky than with eighteenth-century practices. ${ }^{60}$ Straub has himself acknowledged a philosophical indebtedness to Stravinsky in his aesthetic approach to film-making:

The work, for me, when I write an editing sequence, is to arrive at a framework that is completely empty, so that I can be sure to no longer have any intention whatsoever, to no longer have the power to have any while I film. I am always trying to eliminate all intentions-

\footnotetext{
56 “...notre travail sur le découpage ait consisté principalement à effacer toute trace d'intentions, d'expression.” Straub, “Sur Chronique d'Anna Magdalena Bach," 58.

${ }^{57}$ This is not to say that all of these artists' recorded performances on disc are similarly uninflected—quite the contrary—but rather that it is a common characteristic of the performances in this particular film.

${ }^{58}$ Paul Henry Lang, "Editorial," Musical Quarterly 58, no. 1 (January 1972): 118, 124. Lang's critique is all the more striking, considering Harnoncourt's reception by other critics as especially radical and daring. See, for example, Taruskin, "Facing Up, Finally, to Bach's Dark Vision," in Text and Act, 307-15 and Nicholas Kenyon, "Introduction: Some Issues and Questions," in Authenticity and Early Music: A Symposium (Oxford and New York: Oxford University Press, 1988), 4-5. Kenyon cites Harnoncourt's 1968 B Minor Mass recording as particularly revolutionary.

${ }^{59}$ Laurence Dreyfus, "Early Music Defended against Its Devotees," 319-20; Susan McClary, “The Blasphemy of Talking Politics during Bach Year," in Music and Society: The Politics of Composition, Perofrmance and Reception, ed. Richard Leppert and Susan McClary (Cambridge: Cambridge University Press, 1987), 61; Taruskin, Text and Act; and comments by Dreyfus and Taruskin especially in "The Early Music Debate: Ancients, Moderns, Postmoderns."

${ }^{60}$ Taruskin, Text and Act, 60 and 90-154.
} 
the will of expression. That is the purpose of editing. Stravinsky said "I know well that music is incapable of expressing anything at all." I am of the opinion that that is also true for film. ${ }^{61}$

Such a stance is consistent not only with Stravinsky. As Taruskin contends, the prioritization of autonomous and self-contained artworks, the effacement of the artist's persona and the interpreter's subjectivity are also redolent of the post-war "new criticism" movement in literary studies. By extension, he argues, the avoidance of interpretation also characterizes positivist approaches to historical musicology, especially performance practice scholarship. ${ }^{62}$

In Chronicle, however, the style of Baroque performance practice heard in the film is most strongly indebted to another modernist: Bertolt Brecht. During interviews and in quotations in their scripts, Straub-Huillet frequently cite Brecht's writing, and his broader ideological and aesthetic influence on their work has been extensively documented. ${ }^{63}$ In particular, Martin Brady has noted that the "nonpsychological acting" employed by Straub-Huillet in their films is a technique they likely absorbed by adapting Bertolt Brecht's works to the screen. ${ }^{64}$ In Chronicle, the suppression of inflection in the acting as well as the musical performances, coupled with the "distancing" effect of the direct sound and the denial of sensory pleasure from viewing the film, together constitute an "unpleasure" typical of Brecht-inspired counter-cinema. ${ }^{65}$ While Brecht's own work with such composers as Kurt Weill, Paul Hindemith, Hanns Eisler and Paul Dessau has been the subject of much recent scholarship, arguably his influence on twentieth-century musical culture extends far more broadly than his collaborations in music theater. ${ }^{66}$ Chronicle thus exemplifies how Brecht's ideas and aesthetics could shape not only modernist composition, but also interpretations of early music.

\section{Performing Bach as a "Political" Act}

Straub-Huillet's engagement with Brecht led them to develop in Chronicle a kind of politicallyengaged artwork distinct from that of other directors working in the late 1960s, even those at the forefront of the filmic avant-garde. Such was the bewildered reaction of Jean-Luc Godard upon seeing the Bach film, as related by Straub:

\footnotetext{
${ }^{61}$ Le travail, pour moi, quand j'écris un decoupage, c'est d'arriver à un cadre qui soit complètement vide, pour que je sois sûr de ne plus avoir absolument aucune intention, de ne plus pouvoir en avoir quand je tourne. Je suis toujours en train d'éliminer toutes les intentions-les volontés d'expression. C'est cela le cadre du découpage. Strawinsky a dit: "Je sais bien que la musique est incapable d'exprimer quoi que ce soit.» Je suis de l'avis qu'un film aussi. Straub, "Sur Chronique d'Anna Magdalena Bach," 57. Straub also refers to this same Stravinsky quote in Engel, “Andi Engel Talks to Jean-Marie Straub," 14. The original quote appears in Igor Stravinsky, An Autobiography (New York: W. W. Norton, 1962 [original edition Simon and Schuster, 1936]), 53.

${ }^{62}$ Taruskin, Text and Act, 74-75.

${ }^{63}$ Böser, The Art of Seeing, 13; Byg, Landscapes of Resistance, 24; Jenkins, "The Counter-Cinemas of Straub/Huillet and RobbeGrillet"; Walsh, The Brechtian Aspect of Radical Cinema.

${ }^{64}$ Martin Brady, "Brecht and Film," in The Cambridge Companion to Brecht, ed. Peter Thomson and Glendyr Sacks (Cambridge: Cambridge Univ. Press, 2006), 297-317.

${ }^{65}$ For more on the pleasure-unpleasure dialectic in Straub-Huillet's films, see Jenkins, 149.

${ }^{66}$ Michael Gilbert has noted that Brecht himself greatly admired Bach's music and considered it an antidote to the narcotic excesses of late German Romantic composers such as Wagner and Strauss. See Michael John Tyler Gilbert, Bertolt Brecht's Striving for Reason, Even in Music: A Critical Assessment (New York: Peter Lang, 1988), 14-16; 258. As Gilbert further notes, "In general, it should not be forgotten that Brecht's reaction to the use of music as a narcotic was not merely the reflection of some purely artistic or aesthetic doctrine of rationality and sobriety, but rather a measure of his conviction that the present condition of Western civilization called for an aesthetic posture on the part of both the producers and consumers of culture which rejects passive aesthetic contemplation and pleasure for its own sake in favor of an active process of reasoning and learning from which a progressive transformation of society is to result" (259).
} 
He had seen Chronicle at the Locarno festival. He found that, politically, it was missing something. Laughing, I said to him, "Surely you didn't expect me to put at the end 'Everything is political?" He answered, "Ah, perhaps that would have been sufficient."

Godard's lukewarm response to the film is telling, suggesting disappointment with Chronicle's apparent lack of a political message during a turbulent period in which many artists, like Godard himself, were engaging with the radical ideas, situations, language and popular music of youth culture.

However, it would be an oversimplification to view the Brechtian distancing effects in Chronicle as evidence of a purely abstract formalist aesthetic. As in Brecht's own work, these techniques only serve to underscore the leftist political imperative of Straub-Huillet's filmmaking. The project of recreating the conditions of Bach's life and the original circumstances in which Bach's music was performed is likewise not a goal unto itself in Chronicle. Rather, this pursuit of authenticity is connected to a larger political project, through which Bach's life is used allegorically to critique contemporary post-war society. In interviews, Straub-Huillet make clear that their criticism is targeted at four main areas: Romanticism, German denazification and reconciliation efforts, the injustice of West German government film financing and the position of the artist under the capitalist mode of production, and U.S. foreign policy in Southeast Asia. That the conveyance of such an ambitious political agenda might prove problematic in the film's reception is not surprising, an issue to which I will return below.

In their portrayal of Bach struggling against difficult working conditions in Cöthen and Leipzig, Straub-Huillet present a powerful critique of the Romantic idealization of the artist as creative genius separated by his musical talents from more worldly concerns. The straightforward musical performances in Chronicle likewise serve to "get away from 'romantic performance practice," the layers of interpretation which Bach's work has acquired since its rediscovery at the turn of the $18^{\text {th }}$ century." ${ }^{\circ 9}$ In this vein, Caryl Flinn has remarked that the use of period instruments in Chronicle was "a choice [that] insisted on a concrete historical context for a figure whom, as Theodor Adorno argued at the time, Germans had transformed into an ahistorical myth of German nationality . . . [Straub-Huillet's] use of Bach, then, was not just historically appropriate to the film, but helped criticize the contemporary deification that Adorno observed. ${ }^{70}$

However, the purpose of Straub-Huillet's historical contextualization is not only to demythologize Bach's image. It is also to remove Bach from the sphere of Romanticism itself, which Straub suggests has more ominous implications:

Bach is for me one of the last figures in the history of German culture for whom there is not yet a divorce between what one might call the artist and the intellectual; with him, one does not see a trace of Romanticism-we know what in part developed out of German Romanticism; there is not with him the slightest separation between intelligence, art and life, nor is there a conflict between "profane" and "sacred" music, with him everything is on the same plane. For me, Bach is the opposite of Goethe. ${ }^{71}$

\footnotetext{
${ }^{67}$ Biette, "Entretien avec Jean-Marie Straub et Danièle Huillet," 49.

${ }^{68} \mathrm{Byg}$, Landscapes of Resistance, 55.

${ }^{69}$ Böser, The Art of Seeing, 31.

${ }^{70}$ Caryl Flinn, The New German Cinema: Music, History and the Matter of Style (Berkeley and Los Angeles: University of California Press, 2004), 2. For a summary of Adorno's views on Baroque music and the fledgling historical performance movement, see Dreyfus, "Early Music Defended against Its Devotees," 300-303. Adorno is also cited in a contemporary review of Chronicle by Klaus Eder, "Der wiedergefundene Barock," Film (April 1968): 28.

71 "Bach est pour moi l'un des derniers personnages de l'histoire de la culture allemande chez lequel il n'y a pas encore divorce entre ce qu'on appelle artiste et intellectuel; on ne trouve pas trace chez lui de romantisme - on sait ce qui est en partie sorti
} 
Straub not only makes clear his distaste for German Romanticism here, but more importantly, he also insinuates that this movement would have dangerous repercussions in its extreme manifestations. In other words, "we know what in part developed out of German Romanticism": fervent German nationalism and, by extension, Nazism.

In this regard, the relationship between Straub and Huillet themselves and the events of the war take on a particular importance. As French citizens who came of age during the German occupation, Straub (from the contested border region of Alsace-Lorraine) and Huillet would use their filmmaking to critique German culture during and after World War II. In West Germany, the project of post-war reconciliation and confrontation with the recent Nazi past likewise formed important themes in the New German Cinema of the mid-1960s through the 1980s. Although, as Byg notes, Straub-Huillet were somewhat removed from the core group of New German Cinema directors and critics culturally, aesthetically (and geographically, with their eventual move to Rome in 1969), ${ }^{72}$ the films they produced during the 1960s demonstrate a similar grappling with the project of coming to terms with the past (Vergangenheitsbewältigung). ${ }^{73}$ Thus, when Straub, in a 1968 interview, referred to the Bach film as "yet another film about the unresolved German past," ${ }^{, 74}$ he was only partially joking. In Chronicle, this reckoning comes about in a more indirect manner: Straub-Huillet chose an iconic figure from the distant past with which to confront German imperialism in the present. The eighteenth century thus comes to represent a more innocent German culture for Straub and Huillet, one unstained by Romanticism, fascism and Nazism.

Straub has claimed that he was blithely ignorant of Bach's reputation as a well-known and important "cultural monument" when he began working on Chronicle. ${ }^{75}$ One might interpret this as a facetious remark, particularly considering Straub-Huillet's clear imperative in Chronicle to react against Romantic interpretations of Bach's life and music. Straub nonetheless came to realize Bach's iconic status as he encountered resistance to filming, producing and distributing the film. Indeed, eighteenth-century German composers, such as Handel, Beethoven and Bach, had acquired a certain baggage during the war: they were frequently cited as exemplars of the superiority of Germanic culture for Nazi propaganda purposes. $^{76}$

The cinema was one means by which German classical music was promoted during the Third Reich. Since the early 1930s, Adolph Hitler and Joseph Goebbels had recognized the film medium's potential for rallying populist sentiment, and as a result, the German film industry became an important and well-funded propaganda arm of the regime. ${ }^{77}$ One Nazi film subgenre, the historical biopic or

\footnotetext{
du romantisme allemand; il n'y a pas chez lui la moindre séparation entre l'intelligence, l'art et la vie, pas de conflit non plus entre la musique «profane» et «sacrée», chez lui tout était sur le même plan. Pour moi Bach c'est le contraire de Goethe.” Straub, "Sur Chronique d'Anna Magdalena Bach," 58.

${ }^{72}$ Byg, Landscapes of Resistance, 35-39.

${ }^{73}$ Byg, Landscapes of Resistance, 71.

74 "Um daraus einen Witz zu machen, habe ich gesagt, ich mache jetzt wieder einen Film über die unbewältigte deutsche Vergangenheit.” Jean-Marie Straub, Interview with Joachim Wolf, Film (April 1968): 25.

75 "Ich bin ahnungslos und unbelastet gewesen. Erst allmählich und mit den Jahren habe ich erfahren, daß Bach zu den Kulturgütern der Nation zählt...” Jean-Marie Straub, Interview with Joachim Wolf, Film (April 1968): 25.

${ }^{76}$ For a discussion of Bach's appropriation by the Nazis, see Pamela Potter, Most German of the Arts: Musicology and Society from the Weimar Republic to the End of Hitler's Reich (New Haven and London: Yale University Press, 1998), 180, 187, 205-6, 215$16,220-222$.

${ }^{77}$ Linda Schulte-Sasse, Entertaining the Third Reich: Illusions of Wholeness in Nazi Cinema (Durham and London: Duke University Press, 1996), 32.
} 
"Genius film," had a particular morale-boosting, escapist and even moralizing function. By emphasizing the charisma, creativity and leadership qualities of great German cultural figures in the arts, sciences, politics or military, Nazi propagandists sought to draw parallels to Hitler himself. ${ }^{78}$ Eighteenth-century personages were particularly prone to this Romanticized cinematic treatment because of that century's association with the rise of German nationalism, military power, and Enlightenment thought: several biopics focused on the life and works of such canonic figures as Frederick the Great, Schiller and Mozart. ${ }^{79}$ In such "Genius films," as Linda Schulte-Sasse observes, "the Genius, whether artist, scientist, or doctor, is a 'rebel' constrained by a world that fails to understand him and attempts to subjugate him to 'rules,' which are inimical to his 'nature."”80

\section{Video Example 4}

Accessible at: http://dx.doi.org/10.3998/mp.9460447.0005.103

One such Nazi film, Friedemann Bach (1941), is particularly telling in its portrayal of Johann Sebastian's eldest son as a kind of tragic or anti-Genius. ${ }^{81}$ Directed by Traugott Müller, the film presents Wilhelm Friedemann as a tempestuous artist who rebels against his dominating father (here, a surrogate Führer figure), refuses to compromise his art for the good of society, and squanders his talent (see VIDEO EXAMPLE 4). Young audiences throughout the Reich were a particular target of such films. As such, Friedemann Bach was shown not only in conventional cinemas, but also during Youth Film Hours sponsored by Hitler Youth and the League of German Girls. ${ }^{82}$ Given that membership in Hitler Youth organizations became compulsory after 1936, and that the showing of such films extended even to rural areas, schools, church halls, and other public centers throughout the Reich, the reach of this type of propaganda cannot be underestimated.$^{83}$ Remarkably, Friedemann Bach continued to be shown in German cinemas even after the war-as though such a film could be conveniently stripped of its problematic history and now viewed as innocent entertainment. Straub's explicit mention of Friedemann Bach in his 1966 essay on Chronicle suggests that he was familiar with Müller's film:

The film [Chronicle of Anna Magdalena Bach] will really be the opposite of what I read yesterday on a billboard of the Theatiner Filmkunst about the film on Friedemann Bach and which I noted: "His music and that of his father give to the film an abundance of impressive musical summits." 84

Straub-Huillet's treatment of Johann Sebastian and his son Wilhelm Friedemann in Chronicle is indeed quite the opposite of Müller's approach. Wilhelm Friedemann (played by Andreas Pangritz) appears in Chronicle during shot 3, where he plays the Prelude no. 6, BWV 128 from the Notebook for W. F. Bach (see FIGURE 3). While the scene is brief, its appearance near the very beginning of the film highlights its narrative importance. That Friedemann is portrayed here not as a brazen adult but rather as

\footnotetext{
${ }^{78}$ Jo Fox, Film Propaganda in Britain and Nazi Germany: World War II Cinema (Oxford and New York: Berg, 2007, $200-4$.

${ }^{79}$ Schulte-Sasse, Entertaining the Third Reich, 28-31; 147-55.

${ }^{80}$ Schulte-Sasse, Entertaining the Third Reich, 149.

${ }^{81}$ Schulte-Sasse, Entertaining the Third Reich, 203-228.

${ }^{82}$ Hilmar Hoffmann, The Triumph of Propaganda: Film and National Socialism, 1933-1945, trans. John A. Broadwin and V. R. Berghahn (Providence and Oxford: Berghahn Books, 1996), 104.

${ }^{83}$ Hoffmann, The Triumph of Propaganda, 103; Schulte-Sasse, Entertaining the Third Reich, 32.

${ }^{84}$ Le film sera vraiment le contraire de ce que j'ai lu hier sur un panneau du «Theatiner Filmkunst» à propos du film sur Friedmann [sic] Bach et que j'ai noté: «Sa musique et celle de son père donnent au film une abondance de sommets musicaux impressionnants.» Straub, "Sur Chronique d'Anna Magdalena Bach,” 56.
} 
an innocent young boy indicates that Straub and Huillet are explicitly seeking to distance themselves from Müller's film, both in terms of its Romanticized portrayal of the composer, but also in terms of its propagandistic function.

Straub-Huillet's criticisms of the German film industry again resonate with the New German Cinema directors, writers and producers, who were angered by the rapid reintegration of Nazi film workers after the war. ${ }^{85}$ They were likewise concerned with the influx of commercial Hollywood productions into Germany, and criticized the limited state financing for new films. In Straub's view, the state granting agencies' discomfort at confronting the horrors of the immediate past also made it difficult to secure funding for Chronicle, accounting for the eight-year delay in filming such a relatively low-budget film. ${ }^{86}$ Straub eventually secured a modest subsidy from the Kuratorium Junger Deutscher Film, but only relatively late in the production.

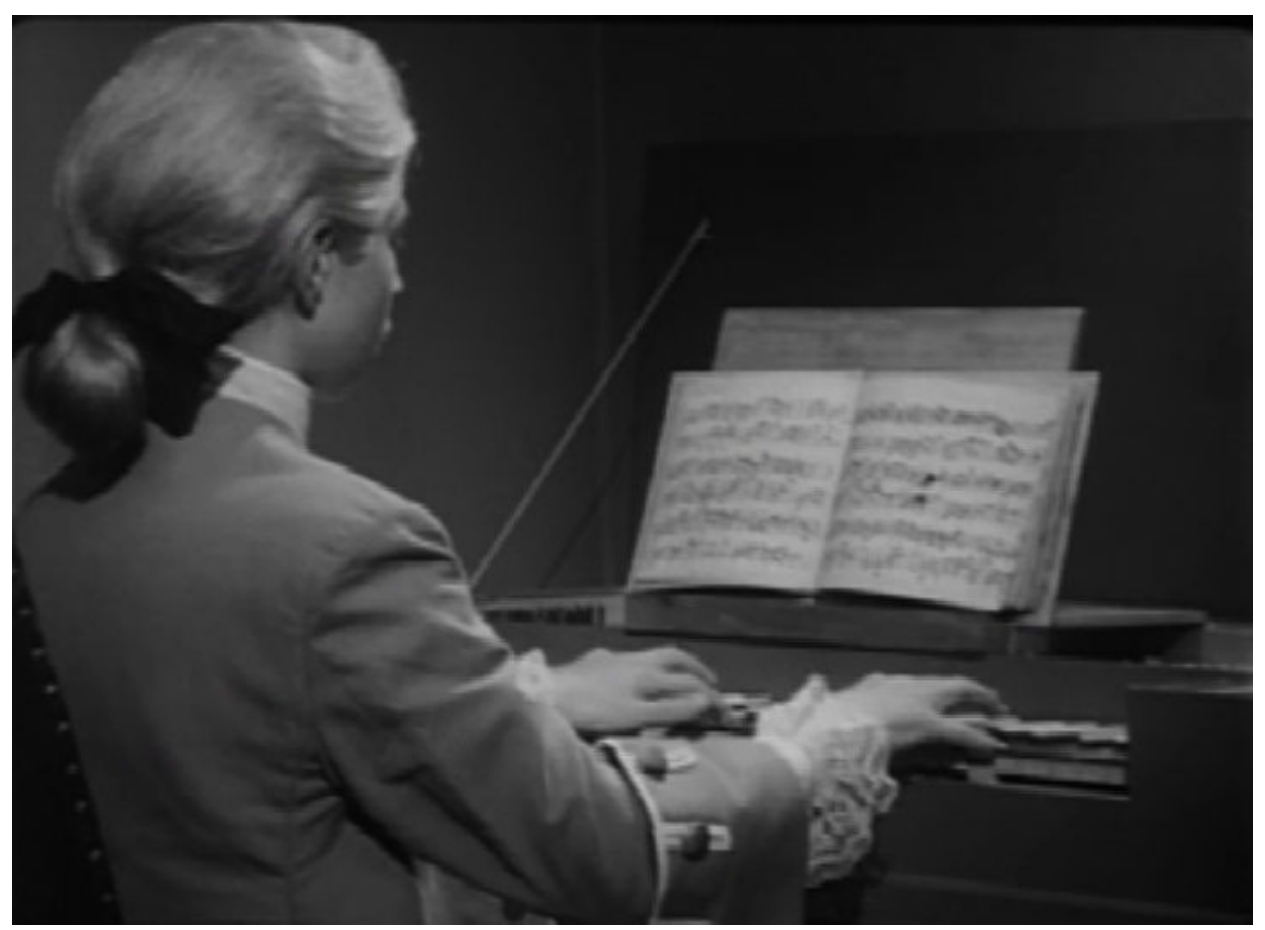

Figure 3. A young Wilhelm Friedemann Bach practices at the keyboard (shot 3).

\footnotetext{
${ }^{85}$ Julia Knight, New German Cinema: Images of a Generation (London and New York: Wallflower, 2004), 10-13.

${ }^{86}$ See Byg, Landscapes of Resistance, 52-54. Straub discusses the struggle to obtain funding at length in Joachim Wolf, Interview with Jean-Marie Straub, Film (April 1968): 25-26 and Engel, “Andi Engel Talks to Jean-Marie Straub,” 1-4. See also "Plaidoyer pour un projet," Cahiers du cinéma 186 (January 1967): 17 and Uwe Nettelbeck, "Plädoyer für ein Projekt. Der Fall Jean-Marie Straub,” Die Zeit, 14 October 1966.
} 
In recounting his struggle to obtain financing and other labor-intensive aspects of Chronicle's production, Straub argues that little has changed in the past two hundred years in terms of the position of the artist in society. He draws a parallel to Bach's own altercations with his Leipzig patrons over money and artistic freedom, remarking that:

Castro or someone else said once, "The revolution is like God's grace, it has to be made anew each day, it becomes new every day, a revolution is not made once and for all”. And it's exactly like that in daily life. There is no division between politics and life, art and politics. This is also why this film interested me; because Bach was precisely someone who reacted against his own inertia, although he was deeply rooted in his times, and was oppressed. ${ }^{87}$

By highlighting labor relations, the labor of producing the film and the collective labor of making music, Chronicle thus becomes not only a film about Bach, but also about the labor of producing art. ${ }^{88}$ Viewed from a Marxian perspective, Chronicle critiques on several levels the exploitation of artists in the capitalist mode of production. ${ }^{89}$

Given their frustrations with the post-war German film industry, Straub and Huillet were careful to distance themselves from it: they frequently emphasized the international nature of Chronicle's cast and crew in interviews. ${ }^{90}$ In this regard, a significant departure from historical verisimilitude in the film takes on new importance: the choice of Gustav Leonhardt to play Bach-that is to say a Dutchman, not a German (and one who, in terms of stature and physique, does not resemble the composer). In an interview in the VARA documentary cited above, Straub articulates an important rationale for choosing Leonhardt to portray Bach (See VIDEO EXAMPLE 5):

\section{Video Example 5}

Accessible at: http://dx.doi.org/10.3998/mp.9460447.0005.103

Something I discovered later is that it was important, simply because ... I wouldn't want anyone to view this as a nationalist statement in any respect, that is...neither anti-, nor something else-but I do believe it is also ... important that the person who, let's say, impersonates Bach in this film-he impersonates Bach after all-is not German. Because of what happened in this country [here Straub pauses to brush crumbs from the table with his left hand] ... mainly between '33 and '45, I am glad to have found a Dutchman. ${ }^{11}$

\footnotetext{
${ }^{87}$ Engel, “Andi Engel Talks to Jean-Marie Straub," 9.

88 "One attraction of the film consists in that we will show people in the process of making music; we will show people who are actually accomplishing work in front of the camera." Straub, "Sur Chronique d'Anna Magdalena Bach," 56. See also Böser, The Art of Seeing, 67. Böser claims that Straub, in the German script of Chronicle (Frankfurt: Verlag Filmkritik, 1969) quotes Marx's Comment on Fames Mill, but I am not able to locate this passage in my copy.

${ }^{89}$ Straub and Huillet acknowledge that Chronicle is a "Marxist film" in a 1970 interview, though Straub qualifies his statement, saying "I know well that I have made a Marxist film; I do not know if I am Marxist. I do not know it, because there are so many ways to be a Marxist" (Je sais bien que j'ai fait un film marxiste, je ne sais pas si je suis marxiste. Je ne le sais pas, parce qu'il y a tellement de manières d'être marxiste.) See Enzo Ungari, "Entretien avec J.-M. Straub et D. Huillet," Cahiers du cinéma 228 (1970), 56-7.

${ }^{90}$ This is mentioned specifically in the VARA documentary cited above. For example, one co-producer (Gianvittorio Baldi), the cinematographer (Ugo Piccone), and members of the makeup and costume crew were Italian; the sound team (Louis Hochet, Lucien Moreau) was French.

${ }^{91}$ This segment occurs at 11:04 in the documentary (see note 53 above). Huillet, seated to Straub's left during the interview, does not speak. Both Straub and Huillet avoid eye contact with the camera throughout. In reference to Leonhardt's lack of association with the Nazi period, Straub makes a similar comment in Wolf, Interview with Jean-Marie Straub, 26.
} 
It is not only, then, that Leonhardt was a skilled harpsichordist, organist and conductor, as was Bach himself. Leonhardt's Dutch nationality also indicated to Straub that he was untarnished by Nazi associations, and thus a fitting choice to portray the composer. Bach's image could be cleansed through "Dutchification," just as crumbs could be brushed off a table.

Straub further defended his choice of the relatively unknown Leonhardt in interviews with the press, noting that his financial backers would have preferred a big-name actor, such as Curd Jürgens, ${ }^{92}$ or a famous musician, such as Herbert von Karajan, to portray Bach. ${ }^{93}$ Not only did Straub-Huillet resent the meddling in their artistic affairs by third parties aiming to increase Chronicle's broader commercial appeal. ${ }^{94}$ Karajan's Bach performances with large modern orchestras were also at odds with the directors' aim to recreate eighteenth-century performing forces. Moreover, they found Karajan's conducting on film particularly distasteful; such a superstar "maestro," with his larger-than-life persona, would have been entirely at odds with a Brechtian estrangement of the artist from his work. ${ }^{95}$

Finally, we turn to perhaps the most controversial political statement by the directors, Straub's oftquoted remark that "the Bach film is my contribution to the fight of the South Vietnamese against the Americans." 96 That a film about a cherished figure of German high culture, dead for two hundred years, could relate in any meaningful way to the political struggles of the Vietnamese was immediately viewed as outlandish by contemporary critics, and as an opportunistic attention-getting strategy. According to Klaus Eder,

Straub's somewhat premature, if also tactically imprudent, remark at a Munich screening drummed up interested (and, after this remark, also irritated some) lenders: his film is dedicated to the Viet Cong, and he hoped that the Viet Cong did not have the difficulties he, Straub, had encountered in making his film in our own society; this remark says nothing about the film itself, but refers only to its production and the difficulties of commercial exploitation faced by Straub now. ${ }^{97}$

Straub himself elaborated further in a 1976 interview:

\footnotetext{
${ }^{92}$ Biette, "Entretien avec Jean-Marie Straub et Danièle Huillet," 47.

${ }^{93}$ Engel, “Andi Engel Talks to Jean-Marie Straub," 3. Although Leonhardt concertized widely and had made several wellreceived recordings by the mid 1960s, he was mainly known to specialists and classical music aficionados at this point in his career.

${ }^{94}$ In another interview, Straub and Huillet recount having received an offer from a German film promoter to both pay Karajan's salary and to offer them twice the amount of financial backing were they to agree to use the conductor in the role of Bach. As Huillet put it, "If we make the film with Karajan, it's no longer our film, it's not what we want to do. So we said no, and that was that." Marie Frering, Bruno Tackels and Nathalie Savey, "Entretien avec Jean-Marie Straub et Danièle Huillet, Strasbourg," in Jean-Louis Raymond, Rencontres avec Fean-Marie Straub et Danièle Huillet (Strasbourg: Limelight; Le Mans: École régionale des beaux-arts, 1995), 53. Straub reiterates this same story in Costa and Lounas's documentary Où git votre sourire enfoui? during a lecture to a group of film students about his life as a filmmaker. The segment occurs at approximately 1:30:21 to 1:131:43 on the DVD. (See note 5 above.)

${ }^{95}$ Biette, "Entretien avec Jean-Marie Straub et Danièle Huillet," 47. Here Straub and Huillet refer to the editing practices in Clouzot's Karajan films, many of which were made during the mid 1960s. It is also possible that Straub and Huillet were familiar with allegations that Karajan was both a Nazi party member and sympathizer.

${ }^{96}$ Straub, quoted in Engel, "Andi Engel Talks to Jean-Marie Straub," 9. The quotation has circulated widely; see, for example, Yaak Karsunke, "Die Vertreibung der Wechsler aus dem Tempel," Film (April 1968): 27; Roud, Fean-Marie Straub, 71; Dermody, "Jean-Marie Straub and Danièle Huillet," 127.

${ }^{97}$ Straubs etwas voreilige, weil taktisch unkluge Bemerkung bei einer Münchner Vorführung vor interessierten (und nach dieser Bemerkung zum Teil verärgerten) Verleihern, sein Film sei dem Vietcong gewidmet, und er hoffe, daß der Vietcong nicht die Schwierigkeiten habe, die er, Straub, beim Drehen seines Filmes in dieser unserer Gesellschaft hatte, diese Bemerkung trifft in nichts den Film selbst, lediglich seine Entstehung und die Schwierigkeiten bei der kommerziellen Auswertung, denen sich Straub jetzt gegenübersieht. Eder, "Der wiedergefundene Barock," 28.
} 
The remark was made as a provocation, and it has little to do with this subject when you understand its context. It was made at a time when the bombardment of Hanoi was at its peak. The film was being presented to some industry people to see if the film was going to be distributed, to see if there was a possibility of distribution in Munich or broader distribution. And that morning we saw in the newspapers that the bombing of Hanoi had begun again, and we said simply, at that moment, showing the film to those people, that the film was dedicated to the Vietcong. We never said it was a contribution to their struggle. Only that the film was dedicated to the Vietcong. And we added that we hoped the Vietcong would not have to struggle on for ten more years against American imperialism, the way we had to struggle for ten years for this film to finance it. ${ }^{98}$

Such a polarizing statement becomes less a critique of American foreign policy in Southeast Asia (though even with Straub's qualification it remains that in part), but rather an attempt to critique the suppression of artistic freedom, and to highlight Straub-Huillet's own struggle in securing funding for the film's production. Ironically, however, the remark about the Vietcong detracted from Chronicle's important political and artistic goals, further confusing its critical interpretation and reception.

\section{Mediating Intention and Reception: Chronicle's Aftermath}

While Straub-Huillet's leftist views are apparent from their statements in interviews, promotional materials and dedications in their scripts, critics have been divided about the extent to which these messages are actually conveyed in their films. As Böser notes, "It is striking that critics' expectation of clear-cut political statements in the films is frequently accompanied by the realization that the films never quite deliver on this perceived promise." Straub and Huillet have been similarly equivocal about the intended audience for their films. At various times, they have claimed that the film was aimed at "an

audience of peasants," 100 "children" or even "cavemen." 101 Again, it is likely such statements are, in Straub's term, a "provocation," particularly in response to assertions by critics that films such as Chronicle are elitist, have little mass appeal, and are best suited to art house audiences. The directors seem to express an interest in attracting a broader audience to their films, yet also unwillingness to compromise their aesthetic and ideological position in order to do so.

In Chronicle, Straub-Huillet demonstrates a distinctly subtle type of politically-engaged filmmaking, one different from Godard, whose films from the late 1960s include sex, violence and situations that might have more popular appeal. Nevertheless, the sobriety of Straub-Huillet's aesthetics and the ambiguity of their political message in part account for the problematical nature of Chronicle's reception. As such, it is possible to detect a general difference in tone in the reaction of American and European critics. American reviewers in the mainstream press who viewed Chronicle shortly after its release generally do not pick up on the leftist political messages underscored in the film, perhaps because they were removed from the direct experience of post-war Germany that might have contextualized Straub-Huillet's Marxist reinterpretation

\footnotetext{
${ }^{98}$ Joel Rogers, "Jean-Marie Straub and Daniele Huillet Interviewed: Moses and Aaron as an Object of Marxist Reflection," Fump Cut 12/13 (1976): 61-64, http://www.ejumpcut.org/archive/onlinessays/jc12-13folder/moses.int.html (Accessed 11 March 2010).

${ }^{99}$ Böser, The Art of Seeing, 20. For a similar point, see also Byg, Landscapes of Resistance, 243.

${ }^{100}$ Joel Rogers, "Jean-Marie Straub and Daniele Huillet Interviewed."

${ }^{101}$ Engel, "Andi Engel Talks to Jean-Marie Straub," 10. Straub has also suggested that the film was well-received even when shown to non-German speakers without subtitles. See Ungari, "Entretien avec J.-M. Straub et D. Huillet," 52.
} 
of a European classical music icon. ${ }^{102}$ As noted above, they tend to comment primarily about Chronicle's sober content and presentation. Typical in this regard are reviewers' remarks in the New York Times ("While this 'Chronicle' is a testament to [Bach's] ever-living music, it is, unfortunately, lifeless as biography") ${ }^{103}$ and Time ("Chronicle of Anna Magdalena Bach is a paralyzed semi-documentary in which the Top 20 Bach hits are rendered by some bewigged court musicians”). ${ }^{104}$

Even in Europe, and even among audiences likely to be sympathetic to their leftist views, StraubHuillet's film was not always well received. ${ }^{105}$ Recounting the showing of Chronicle at the Berlin Film Festival of 1968 ("a somewhat eventful year"), Danièle Huillet relates that, "We refused to go because of the police presence. It seems that there was a kind of struggle in the hall, people who were yelling 'Bach war doch kein Hampelmann', which means: 'But Bach was not a puppet." ${ }^{106}$ Huillet explains that it was not only that the audience was reacting to the "counter-use" of Bach, but also to the challenge the film presents to the nineteenth-century idea that "art is above everything," an idea "amplified by people like Karajan." ${ }^{107}$ However, it is also possible to interpret the audience's reaction as an objection to a twentiethcentury Marxist interpretation imposed upon the life of an eighteenth-century composer.

Moreover, the mixing of leftist politics with Bach's life and music may also have been foreign to the views and experiences of the musicians who participated in the film. As Gustav Leonhardt noted in a recent interview with this author,

Of course, the film was not liked by everybody. It's very austere, for one thing. And then, unfortunately, Straub was not very diplomatic. He had a message with the film, but then I admire him so much for the fact that that message, which was ultra-left, was not to be found if you look and listen to the film. So I think that's a sign of greatness . . . because he didn't project his own views on society, on Bach, or on the period. He did not project-he wanted to, and he intended to, but only [did so in] speaking about the film. And, as he often had to make press conferences, I was sometimes with him, and I felt sorry for him. Because he really spoiled the whole thing for himself and for the film by explaining that it is a film on work, and with Mao, etc. The ultra left element came so clearly that many people didn't want it. Nor did I-I felt sorry. I felt only sorry; I think it's silly what he said, because the film doesn't show that. ${ }^{108}$

While he was careful to distinguish his own views from those of the directors, Leonhardt defended Straub's honesty and integrity, and expressed his appreciation for both the thoroughness of Straub and Huillet's extensive research on Bach and the artistic achievement of the film.

Leonhardt's remarks, which argue for a differentiation of Straub's political views from his work as an artist, are particularly noteworthy considering later developments in the post-war historical performance movement. For Straub-Huillet, the pursuit of historical authenticity, sobriety and anti-Romanticism in Baroque performance as presented in Chronicle were closely connected with Brechtian alienation and

\footnotetext{
${ }^{102}$ In this regard, using a European "high art" icon such as Bach as the subject for a film, while also thwarting Hollywood cinematic conventions, could also be viewed as an implicit critique of American popular culture.

${ }^{103}$ A. H. Weiler, "Screen: 'Chronicle of Anna Magdalena Bach’ Opens,” New York Times, 7 April 1969, p. 49.

104 "Cinema: A Festival of Diamonds and Zircons," Time, 27 September 1968. For summaries of additional contemporary reviews in the American press, see Filmfacts 12 (1969): 282-83.

${ }^{105}$ See also the Volkskrant review cited above.

${ }^{106}$ On a refusé d'y aller parce que la police était très présente. Il paraît qu'il y a eu une sorte de combat dans la salle, des gens qui hurlaient: "Bach war doch kein Hampelmann», ce qui veut dire: «Bach n'était pourtant pas un pantin.» Biette, "Entretien avec Jean-Marie Straub et Danièle Huillet," 47.

107 "Les gens découvraient que Bach avait des autorités au-dessus de lui et qu'il composait aussi de la musique fonctionnelle. L'idée du XIXe siècle, c'était que l'art était au-dessus de tout. Et cela a été amplifié par des gens comme Karajan.” Biette, "Entretien avec Jean-Marie Straub et Danièle Huillet," 47.

${ }^{108}$ Gustav Leonhardt, interview by author, 3 July 2008, Amsterdam, The Netherlands.
} 
Marxist social critique. However, for many historical performers (unaware of, or perhaps disenchanted with, the particular political angle espoused by Straub-Huillet), the goal of realizing the composers' intentions became a primary pursuit in and of itself. A rigorous, "straight" performance style—in other words, the particular interpretive stance Taruskin describes as "letting the music speak for itself," became reified, and separated from the distinct political context and historical moment in which it developed.

Thus, one of the most significant-if unintended-outcomes of Chronicle was that the quest for authenticity in the performance of Baroque music came to take on an independent life beyond the film. That such an authenticity pursuit had limitations became one of the primary lines of criticism lobbed at historical performers, especially from the late 1960s through the 1980s. ${ }^{109}$ Such criticism was articulated on two main fronts: firstly, that objectivity and authenticity in performance are illusive, and the attempt to remove subjectivity in performance is itself a form of interpretation; ${ }^{110}$ and secondly, that authenticity came to be used as both a vapid marketing label and as a moralizing term with which to castigate performers on conventional instruments. ${ }^{111}$ Yet a third critique has also been made on historical grounds: in other words, that a "literalist" or "straight" approach to playing Baroque music is at odds with seventeenth- and eighteenth-century musical aesthetics, such as the Affektenlehre (Doctrine of the Affections), and the contemporary belief that music should move the listener's passions. ${ }^{112}$ An examination of primary sources by Caccini, Mace, Tosi, Mattheson, Marpurg, C.P.E. Bach, Quantz and others indicates that fluctuations in tempo or rhythmic flexibility played an important role in heightening the affective communication and expressive performance of many works, particularly those with text (such as recitatives) or in a free, improvisatory style. ${ }^{113}$ According to this reasoning, a literalistic pursuit of authenticity in the 1960s and 70s resulted in the suppression of all expressive aspects of performing, which were incorrectly lumped together with Romanticism; such a proverbial throwing out the baby with the bathwater lead historical performers to overlook evidence that might favor more nuanced interpretations. An examination of such sources might suggest alternatives to the strictly regular Bach performances heard in this film, particularly the vocal works.

A second unintentional outcome of Chronicle is that it invested both Leonhardt and Harnoncourt with authority in the field of historical performance. By featuring Gustav Leonhardt as Bach and his Austrian colleague Nikolaus Harnoncourt as Prince Leopold of Anhalt-Cöthen, Straub-Huillet accorded them status (for portraying Bach himself was high praise indeed!) and emphasized their positions as leaders of the postwar historical performance movement. If Straub could claim that the time of filming

\footnotetext{
${ }^{109}$ As Dorottya Fabian has observed, the word "authentic" was beginning to be used as a marketing tactic by recording companies and in the popular press by the mid-1960s, and it often appears in English, French, German and Dutch reviews of Chronicle. See Fabian, Bach Performance Practice, 1945-1975, 13. Debates regarding authenticity in performance heated up considerably in the 1980 s with the launch of the CD format and an increasing use of the term in marketing campaigns by record companies and concert promoters. See Kenyon, "Introduction: Some Issues and Questions," 6; and Taruskin, Text and Act, 90, 152-53.

${ }^{110}$ Dreyfus, "Early Music Defended against Its Devotees," 300-301.

${ }^{111}$ Taruskin, Text and Act, 92.

${ }^{112}$ See, for example, Gregory Butler, “The Projection of Affect in Baroque Dance Music," Early Music 12, no. 2 (May 1984): 201-7; George J. Buelow, "Johann Mattheson and the Invention of the Affektenlehre," in New Mattheson Studies, ed. George J. Buelow and H.J. Marx (Cambridge: Cambridge Univ. Press, 1983), 393-40; Frédéric Dassas, and Barthélémy Jobert, eds., De la rhétorique des passions à l'expression du sentiment: actes du colloque des 14-16 mai 2002 (Paris: Cité de la musique, 2003).

${ }^{113}$ See, for example, Richard Hudson, Stolen Time: The History of Tempo Rubato (Oxford: Clarendon Oxford, United Kingdom, 1994) and Carl L. Blake, “Tempo Rubato in the Eighteenth Century,” D.M.A. Diss., Cornell Univ., 1988. Hudson (438-39) argues that a neo-Romantic backlash to the straight style of Early Music performance was developing by the late 1980s, characterized by renewed interest in tempo rubato.
} 


\section{Music and Politics Winter 2011}

Leonhardt "had no commercial value," of the film's premiere. Leonhardt and Harnoncourt eventually acquired a certain status not only as successful recording artists, but also as father figures of the post-war historical performance movement. ${ }^{115}$ Moreover, it is ironic to note that the very concept of authenticity-though it developed in part as an outgrowth of a Marxist film project—was itself subject to cooptation by capitalist interests, and exploited by record companies as a marketing tactic. ${ }^{116}$

The Chronicle of Anna Magdalena Bach, as a document from 1968, is thus representative of a defining moment in the Early Music movement, providing insight into the origins of the modern approach to Baroque performance practice. Acknowledging that "Early Music" performing styles have changed over time reminds us that other interpretations of Bach's music are also within the realm of historical possibility. Chronicle is also a sobering reminder that, while we may pretend otherwise, both the creation of biography and musical performance are interpretive acts.

\footnotetext{
114 “On a donc attendu pour faire notre film avec Gustav Leonhardt. Il se trouve qu'à l'époque, personne ne le connaissait. Tout le monde nous disait, même les musicologues, pas seulement les marchands de soupe du cinéma : qui que c'est que ça?». Il n'avait aucune valeur marchande." Raymond, Rencontres avec Fean-Marie Straub et Danièle Huillet, 53. Straub also reiterates this point during the Costa/Lounas documentary (see note 94 above).

${ }^{115}$ Even in 1972, Lang had warned that period instrument performance-with reference to Harnoncourt—might "congeal into a well-regulated cult almost as objectionable as the unrestricted freedom of interpretation it replaces." Lang, "Editorial," 119.

${ }^{116}$ For a discussion of this cooptation, see Haskell, The Early Music Revival, 129 and Taruskin, Text and Act, 343.
} 